\title{
Odum's dark bottle and an ecosystem approach
}

\section{Brian Cook}

University of South Florida, School of Architecture \& Community Design, Tampa, USA 


\section{Abstract}

Eugene Odum was an ecological pioneer, writing the discipline's first textbook, Fundamentals of Ecology, in 1953. Although his work is almost 70 years old, it laid the groundwork for contemporary landscape systems thinking. Since Odum's time, a lineage of ecological research and theory has helped to define concepts pertaining to ecology, ecosystems, and nature. With these terms in peril of becoming ambiguous, especially in the design arts, this chapter revisits the origins and development of ecologic thinking in order to construct a more critical understanding of nature, and the role of the designer for Building with Nature.

One particular experiment by Odum is used as the foundation of concept development. A pond is his reference site and he 'dissects' it, using dark and light bottes to illustrate its nuances and the overall ecosystem idea. Three important principles can be derived. First, the ecologist, or the designer, should understand the 'nature' of the system, or site, where they are working. Second, nature is formed through functional interactions over extended periods of time. Lastly, through an ecosystem approach, it is shown that systems involve indirect effects. In ecological networks, sites are impacted by forces beyond their immediate boundaries, as well as through other social and cultural systems. Case studies located along the Florida Gulf Coast are used to explain Odum's and others' concepts. Florida has developed in parallel with human's capacity to manipulate their environment. For this reason, it is a useful reference site, illustrating trajectories in ecological thinking.

\section{KEYWORDS}

Environmental design, ecological design, Build with Nature, ecosystem approach, landscape architecture, ecological planning 


\section{Introduction}

In the field of ecology, the term ecosystem has been synonymous with nature for almost 100 years (Tansley, 1935; Odum, 1953; Egerton, 2017). When first introduced, it marked a radical shift in the environmental sciences. Prior, concepts of nature were influenced by those in fields like biology, zoology, or in natural history (Benson, 2000). Flora and fauna were studied as objects, independent from their surroundings, each with unique attributes and behaviors. However, in 1935, British botanist Sir Arthur Tansley proposed a term that would reframe the ecologic perspective. An ecosystem, he wrote, provided a more holistic and interconnected model. "Our natural human prejudices force us to consider the organisms ... as the most important parts of these systems, but certainly the inorganic 'factors' are also parts - there could be no systems without them," he wrote (Tansley, 1935). He suggested moving beyond an object-based mode of inquiry, to one where object, humans and environment are studied together, and that elements be put into a multi-scalar context, "from the universe to the atom." (Tansley, 1935; Golley, 1993; Egerton, 2017). Although the term ecology had been used before in the sciences, Tansley and those after him thoroughly transformed it and gave it a dynamic new direction (Benson, 2000).

At the center of this development was a young professor at the University of Georgia who would change the broad understanding of ecology, and of nature, for all future generations, so much so that he is now considered "The Father of Modern Ecology" (Craige, 2001). Dr. Eugene Odum received his $\mathrm{PhD}$ in zoology with a major in ecology in 1939. At first, he was mostly fascinated with birds, but that path of study led him to a job researching plant succession at a biological research station. While performing those duties he began a transition, one that put his attention towards the dynamic nature of a site, and how it functioned as a system. "Only by knowing the nature, extent, and speed of changes as well as factors causing them can man intelligently control his environment in the future," he wrote in a report (Craige, 2001; Odum, 1940). He was also greatly influenced by his father, a prolific sociologist that believed in holism and recognized the influence of context on communities (Craige, 2001; Eagerton, 2017). Odum picked up on Tansley's and others' ideas and brought ecology and ecosystems to the masses, producing the discipline's first textbook Fundamentals of Ecology in 1953. His book described experiments and explained natural processes so that students could understand ecosystem thinking. Through real-world case studies, he provided new imagination as to the interconnected nature of our world. He also discussed the value of operating at, and becoming familiar with, various scales. "When someone is taking too narrow of a view, we may remark that he cannot see the forest through the trees," he writes. "Perhaps a better way to illustrate the point is to say that to understand a 
tree, it is necessary to study both the forest of which it is a part as well as the cells and tissues that are part of the tree." (Odum, 1963).

This chapter will return focus to the origins of ecology and to the ecosystem approach, not only in Odum's work but also in others' development of these concepts. This is important since, in recent years, terms like ecology and ecosystem have become somewhat ambiguous, often referencing definitions more closely associated to historic concepts in the sciences (Benson, 2000; Reed \& Lister, 2014; Craige, 2001). Chris Reed and Nina-Marie Lister, a landscape architect and ecologist, recently wrote that, "Today 'ecology' has been co-opted to refer to almost any set of generalized ideas about environment or process, rendering the term essentially meaningless." (Reed \& Lister, 2014). For design fields like architecture, landscape architecture and engineering, this has had significant impact, affecting overall approach and project outcomes (Reed \& Lister, 2014).

By revisiting the ecosystem approach, in both its origins and development, it may be possible to better situate humans within their world, and to suggest new potentialities and responsibilities for Building with Nature. This chapter will identify examples from various stages in ecological thinking in the Florida Gulf Coast, to correlate theory with real-world implementation and environmental response. Florida has been inhabited in parallel with humans' significant ability to alter their environment but also with change in ecological perspective. The landscape itself shows evidence of a graduated development in ecological thinking (see Spirn, 1998).

\section{The Pond, Dissecting Tools and the Dark Bottle}

Odum liked to use a pond as his reference site. For him, it beautifully illustrated many fundamental ecologic principles (Odum, 1971, Willis, 1997). "Let us consider the pond as a whole as an ecosystem..." Odum began. "The inseparability of living organisms and the nonliving environment is at once apparent with the first sample collected. Not only is the pond a place where plants and animals live, but plants and animals make the pond what it is. Thus, a bottle full of the pond water or a scoop full of bottom mud is a mixture of living organisms, both plant and animal, and inorganic and organic compounds." (Odum, 1971) Odum's pond is a system, an infinite macrocosm of parts relating across and through multiple scales, each element necessary and affecting each other. This, he would write, was nature (Odum, 1971).

In order to conceptualize this further, Odum conducted an experiment using pond water and multiple glass bottles, appropriately called his "dissection tools" (Odum, 1971). He filled the bottles with water from varying depths, wrapping a few of them with foil, which darkened them from sunlight. The 
light and dark bottles were suspended in the pond at the same depth where the water came from and after 24 hours they were removed and processed to measure oxygen content. In the dark bottles, oxygen levels had decreased. It was consumed but not produced. Phytoplankton, which is responsible for oxygen production, was subjugated by the foil and not able to do its work. Conversely, in the clear bottles oxygen was produced in excess. This is representative of the upper levels of the pond. There, phytoplankton supplies enough oxygen to sustain itself, but also the bottom dwellers. There, at the bottom, soil and nutrient is created through decomposition and consumption of detritus by saprotrophic organisms, an important aspect of total system health. Each element acts individually but also as a system, perpetuated by unit adaptation to place. The relationships are co-dependent and are supported by each other's function. Odum explains the importance of recognizing these hidden members of the community: "Although we regard microorganisms as 'primitive,' man and other 'higher' organisms cannot live without ... the 'friendly microbes'; they synthesize necessary organics and provide the 'fine tuning' in the ecosystem since they can adjust quickly to changing conditions" (Odum, 1971). He goes to great length to discuss the importance of detritus and pond functionality at the bottom, as well as the functions at the pond edge, in the middle, and in gradients in-between (Odum, 1971). Light and dark zones, top and bottom levels of the pond, they each have a functional relationship in the production and processing of nutrients and in perpetuating the existing environment (Odum, 1971; Odum, 1963). They support each other. With this in mind, we can begin to visualize the pond in a different way. It is not comprised of isolated components but is rather the cumulative set of agents that aggregate to make up its ecosystem, to form its nature (Holling, 1973; Pyne, 2010).

Odum also discussed, for the pond specifically, how the synergy of parts within the pond developed over time (Odum, 1971). Through competition, adaptation, and by finding the right fit, the components create a complex web of interconnected functionality (Odum, 1963; Benson, 2000; Hutchinson, 1957; McHarg, 1969; Henderson, 1913). This occurs through constant exchange, with things impacting other things within the system. Elements co-evolve to meet criteria related to specific attributes of place and context, in order to produce a dynamic that perpetuates existence (Pyne, 2010; Holling, 1973). This process occurs over time. In an attempt to create a definition, one could say that something's nature, or nature in general, is the resultant of a process where elements within a system interact with each other over time.

Lastly, Odum described the concept of a watershed. He acknowledged that the pond is often falsely perceived as a self-contained unit, defined by a geographic boundary, and that the success and failure of its system is often evaluated in a limited manner. "It is the whole drainage basin, not just the body of water, that must be considered as the minimum ecosystem unit...," he wrote 
(Odum, 1971). He went on to suggest that the cause of and solutions for water pollution are not to be found by looking only into the water. "It is usually the bad management of the watershed that is destroying our water resources" (Odum, 1971). He emphasized the importance of a holistic, systems-based perspective. "Since the ecosystem is primarily a unit of function, just where one draws a line between one part of the gradient and another is not particularly important" (Odum, 1971). His focus was wholly on how the system worked, its inter-relationships, and in defining site by functional rather than locational connections.

There have certainly been many advancements in ecological studies since Odum's time, and these will be discussed, but a critical analysis of his experiments can help to derive a main set of principles to guide future work in environmental design and for Building with Nature. A larger framework is also developed through this text. If nature is the result of relationships, and humans are part of the milieu, then we must consider nature not as something to build with, as a thing apart, but as something that we are within (Gunderson \& Holling, eds., 1995, as cited in Reed, C. \& Lister, N. -M., 2014). If we are within the system, as a productive agent, intertwined and in relation, then we must also acknowledge the productive role of humans, especially now in the Anthropocene: we Build our Nature (Jordan III, 1994; Vitousek, 1997).

\section{Principle \#1: Identify and Incorporate Landscape Systems}

The question of "Building with Nature" points to a question of cognition. What is it that is being worked with? What nature is being engaged and perpetuated by the project? In the transition from pre- to post- ecosystem thinking, Odum, Tansley and others helped to visualize an interconnected world. Odum's textbook drew upon an accumulating body of research, by authors like Henry Cowles, Frederic Clements, Henry Gleason, Victor Shelford and Evelyn Hutchinson, who had already written about functional interrelationships between things in the environment (Egerton, 2017). At the time, these researchers were also developing new forms of representation. Drawings of landscapes began to depict systems, not just objects. This was new science, and a new approach. The first food web diagram had been published by Lorenzo Camerano, in 1880, (figure 1) (Bersier, 2007; Egerton, 2007), however it was not until 30 years later that a steady stream of food web diagrams were produced. Pierce, Cushman and Hood constructed the next example in 1912. Another, by Victor Shelford (figure 2), continued the trend in 1913 (Bersier, 2007; Egerton, 2007). From there, a new form of landscape depiction developed to more holistically describe sites and their ecosystems. 


\section{Mapping Functional Relationships}

Odum takes something familiar, the pond, and reveals a world of functionality and interrelationships that lurk beneath the immediate and obvious. He guides his readers beyond visual perception to one of function, range and scale. It provides a change of optics. Through the discussion of his experiment, he is able to re-map a person to place, giving them a new foundation from which to go forward, and to guide future decision-making.

Upon first encounter, the pond is a water body. It is clear, or not, has fish, or not, and often has plants around the edges. With a more detailed analysis, the pond is also comprised of smaller elements responsible for its physical characteristics.

Phytoplankton, as an example, is found in the upper levels of the pond where light is able to penetrate and it provides oxygen and food for fish and plants. Odum points out that "these producers are not visible to the casual observer and their presence is not suspected by the layman. Yet, in large, deep ponds and lakes phytoplankton is much more important than is [the more visible] rooted vegetation in the production of basic food for the ecosystem." (Odum, 1971). Bacteria and fungi are also working within the pond, as are insects, their larvae, and a host of living and non-living elements that make up its total set of components. Odum, and others, go further, however, to point out that it is not their singularity that makes up their nature, but rather the functional relationships between them, as an ecosystem (Odum, 1971; Lister, 2008; Holling, 1973). These elements are doing things to or for or against each other and this exchange produces ecological effects.

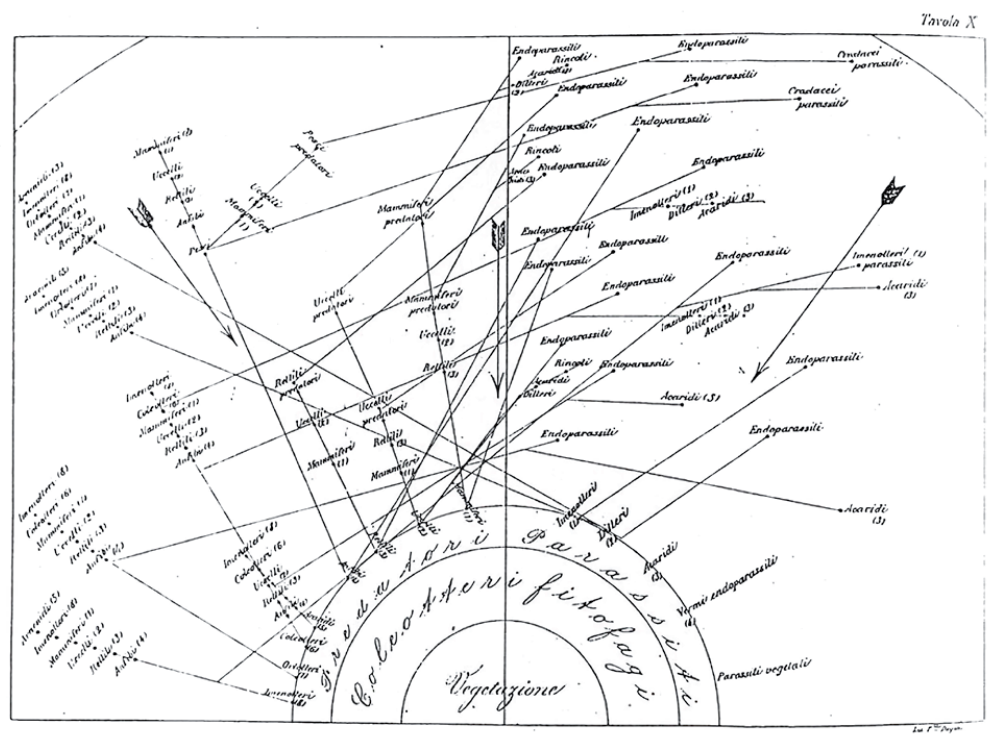

Figure 1. The first known documented food web diagram, by Lorenzo Camerano in 1880. 


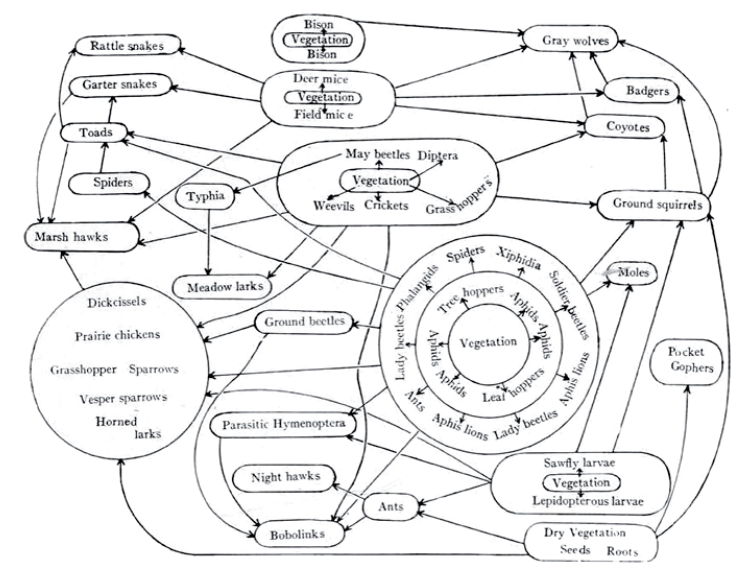

Figure 2 Victor Shelford's diagram from 1913, showing food relations of land animals.

To transpose Odum's understandings to design, it is important to consider the complete system, and not just appearances. He suggests that we are not able to understand something's nature through vision. It takes science and experimentation to dig into what can be considered an infinite world, or eco-system, comprised of a network of interconnected elements. The complexity involved in an ecosystem approach is certainly one of its difficulties and is recognized as a reason why reductive models are more prevalent (Craige, 2001; Bersier, 2007). This has been found true in the sciences but also in the design professions (Brown \& Corry, 2011; Reed \& Lister; Steiner, 2002; Weins, 1992). It is more common for practitioners to analyze their sites formally or aesthetically, or to select a few prioritized attributes despite an awareness that others may exist (Carpenter et al., 2009; Brown \& Corry, 2011). However, a return to Odum's experiment can provide a useful perspective and approach for ascertaining a more complete understanding of site (figures 3 and 4).
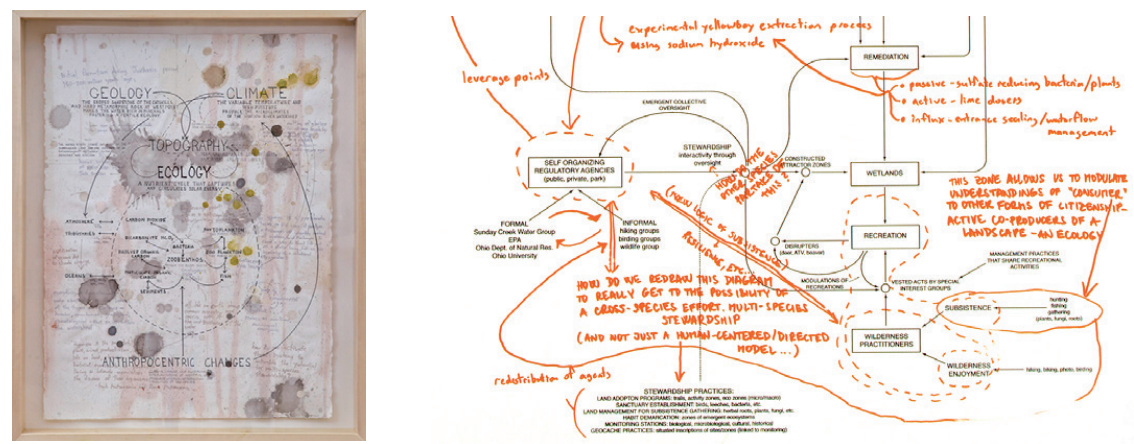

Figure 3 (left). Ecology diagram by Spurse, a contemporary environmental design office that consistently uses diagram in their projects to engage the ecosystem of the project. Image courtesy of Spurse.

Figure 4 (right). Diagram by Spurse. Enlarged detail. Image courtesy of Spurse. 


\section{The Effects of Cultural Bias}

When regarding the Gulf Coast of Florida, these same principles can be understood through a trajectory of projects and manifestations of environmental design. The peak of development in Florida occurred with the advent of modern technologies in the 1950's and 1960's (Smith, 2005). Also, at that time, the population was comprised of people from many other places, from within and outside of the United States (Smith, 2005). This largely foreign population was working within a new territory. Developers had quick profits in mind and were focused on cultural considerations such as finances and views to the sea. With little regard as to the ecological underpinning of coastal environments they began to reshape their surroundings. The government supported this by passing the Riparian Act (1856) and the Butler Act (1921), which allowed land owners to "obtain title to submerged lands adjacent to their uplands by bulkheading, filling or permanently improving submerged lands" (Steinmeyer, 1999). This prompted removal and displacement of existing mangroves, wetlands and marshes and filled lands for ownership. After a surge of development, many thousands of acres of coastal water had been transformed in places like Boca Ciega Bay in St. Petersburg (1953), Cape Coral near Fort Myers (1957) and Marco Island near Naples (1960's) (figures 5 and 6).
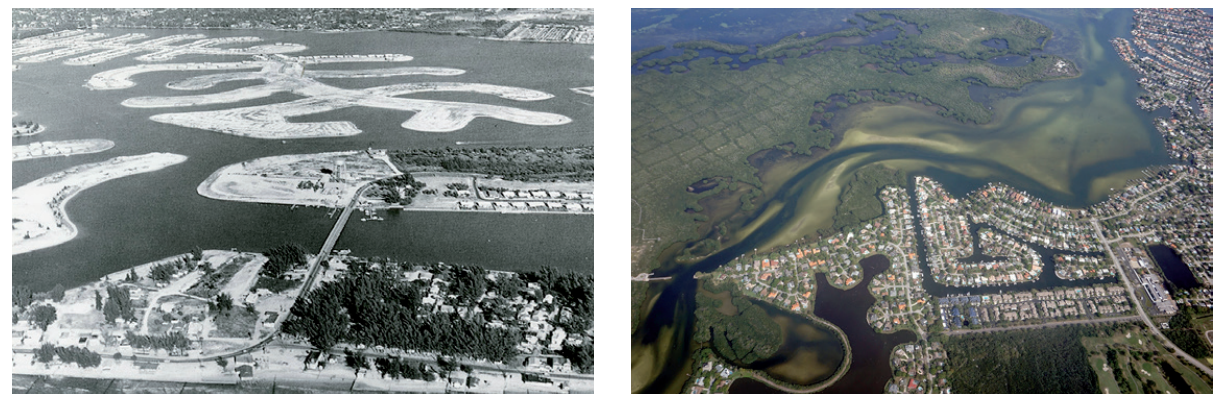

Figure 5 (left). Aerial view of the construction of islands in Boca Ciega Bay, near St. Petersburg, Florida. With permission from Archives and Library, Heritage Village.

Figure 6 (right). Aerial view of St. Petersburg development. Image by Brian Cook.

Sea walls separated property from the waters, allowing property ownership to assume use to the edges (Parsons, 2015). Many miles of coastal gradient were lost and ditching, canals, rip rap and boat wakes ultimately have caused multiple scales of anthropogenic change (Peterson \& Lowe, 2009). Similar to the darkened bottle, the system shifted and existing functional relationships were displaced while others were allowed to become more dominant within the ecosystem. Without the incorporation of landscape function into the region's development, a new nature formed. There have been major impacts such as algal blooms, marsh and mangrove loss and a reduction in fisheries production (Peterson \& Lowe, 2009). 
Similarly, in the City of Tampa, intense building within the floodplain created a situation where urban environments were increasingly flooding. When Hurricane Donna passed through in 1960, neighborhoods flooded and people demanded protection from the United States Army Corp of Engineers (Foley, 2007). The Corp's approach was focused. The directive was to simply move water to the bay, bypassing the city and provide relief from flooding. With this approach and bias, they developed a project and trenched 22.5 kilometers (14 miles) from an inland point around the city, constructing a bypass into McKay Bay (figure 7).

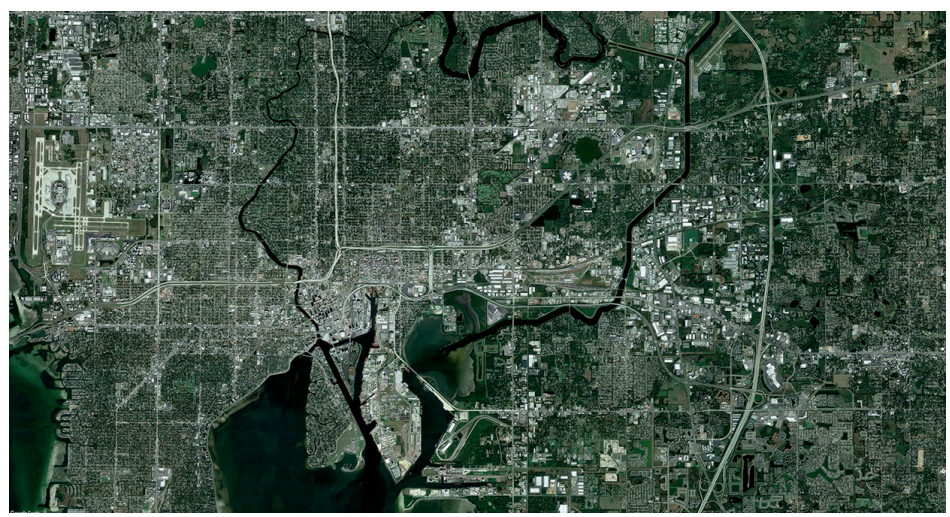

Figure 7. Aerial view of the City of Tampa. The Hillsborough River crosses the north end of the image from east to west, and connects to the bay. The Bypass Canal (named C-135) extends from the northeast of the city southward, bending west into McKay Bay and the port. Map data from Google (c2019.

With control structures and monitoring, this route eliminated all threats of severe inland flooding for the region (Foley, 2007). It has also functioned as a reservoir to supply drinking water. One can critique, however, using Odum's perspective, whether the engineers took an ecosystem approach, and can evaluate what elements they prioritized in the system. Their decisions enabled new opportunities for people, including safety. But with cultural successes, the landscape systems were not well represented, and have since diminished. The waterway did not incorporate attributes of the existing biotic functionality or the scalar landscape relationships, and now are a different projection of nature in that place (PBS\&J, 2010). One could say that the Army Corp, in their design efficiency, was focused solely on the cultural aspects of the project. The final construction provided a corridor for water movement but not all of the complexities and ecologies associated with the historic riverine ecosystem, the one that so many other regional elements were built upon $^{1}$.

1 Readers should also reference David Fletcher's Flood Control Freakology (2008), which highlights other potential river ecologies, beyond those that are typically identified. This article suggests an expanded perspective for the nature of rivers. 

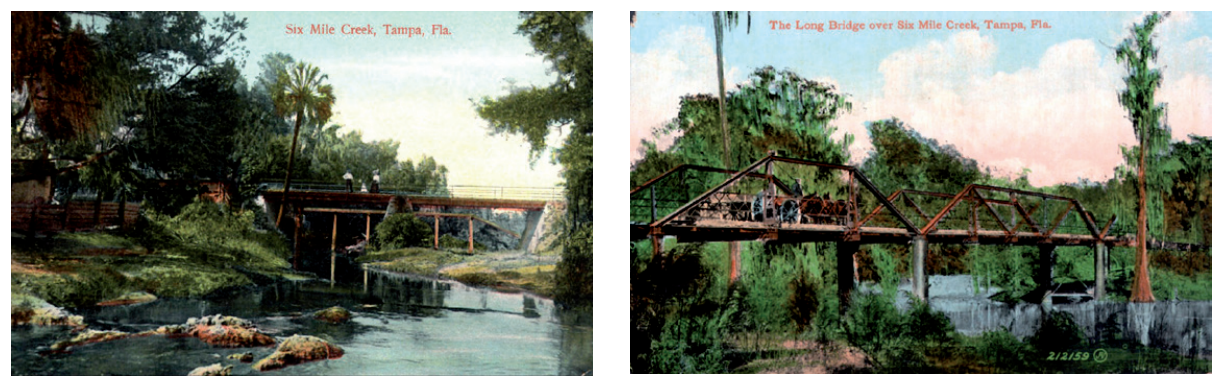

Figure 8 (left). Historic postcard of Six Mile Creek, in Tampa, which extended northward from the Palm River. This area was displaced by the construction of the Tampa Bay Bypass Canal (C-135).

Figure 9 (right). Historic postcard of Six Mile Creek, showing the overall dimension and depth of the area.

In addition to cutting through upland areas, the Bypass Canal displaced the shallow Palm River (figures 8 and 9). Within the new configuration, depth and breadth were spatially maximized. River bank slopes were built as steep as allowable, and riprap was used to prevent erosion. An offset distance from the water's edge has been maintained by mowing and spraying of vegetation, to keep it in control, and to prevent vegetative growth (figure 10).

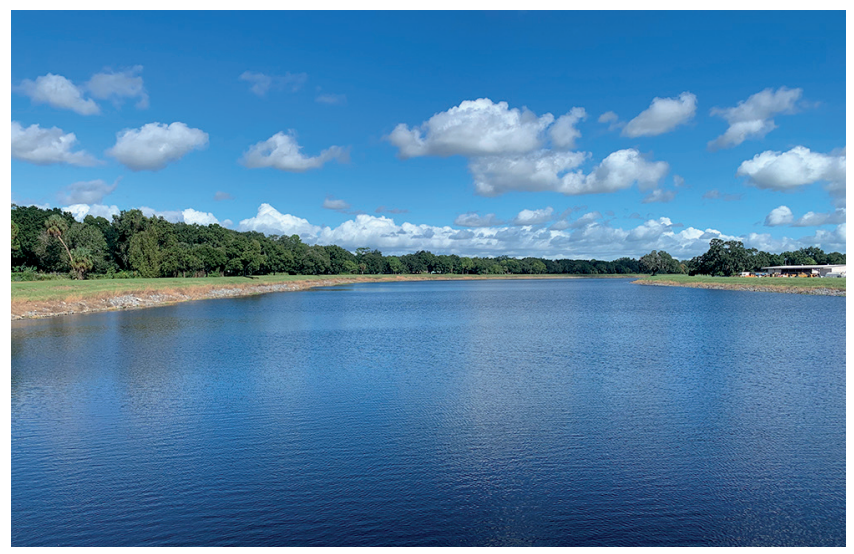

Figure 10. The Tampa Bay Bypass Canal (C-135), in the location that was once Six Mile Creek. Image by Brian Cook.

More importantly, the functionality of this new ecosystem has shifted the nature of the region. In 2002 reports noted that "the canal bottom is virtually devoid of life," despite its situation in a highly productive estuary environment (PBS\&J, 2010).

In 1997, scientists said that the "Palm River has the worst quality of any system in Tampa Bay," that it has "algae blooms all year round," and that it was a "killing field." (Foley, 1997). A 2010 report by the Tampa Bay Estuary Program explained that "the historical riparian emergent tidal wetland habitats in the Palm River were completely altered by dredging and filling. There are virtually no submerged habitats in the [Bypass Canal] due to steep channel side slopes. 
Therefore, the existing habitat values and functions in the tidal portion of the [Canal] are very poor," with "high salinity levels" and "oyster mortality," "hypoxic (low oxygen) and periodic anoxic conditions that result in depauperate benthic communities" (PBS\&J, 2010).

During this history in Tampa Bay, there was a focus on the immediate, the cultural and the surficial aspects of environment. A holistic vision of landscape systems and interrelationships was not part of the construction, either in process or implementation. Because of this, similar to the darkened bottle, there have been severe consequences and a resultant change to the nature of the region.

\section{Principle \#2: Construct Relationships Over Time}

In his texts, Odum repeatedly expressed that an ecosystem is comprised of functional relationships, and that these functions occur over time (Odum, 1971). For instance, in his representation of the pond, he spoke of its "metabolism" and described processes that were occurring within the water, such as production, consumption and decomposition (1971). The foil, darkening the bottle, was inserted as an actor, which induced change by altering the functionality of the system. The system adapted, filling itself with components that are capable of surviving within the given milieu (Odum, 1971, Holling, 1973).

Whereas Odum's example occurs in a relatively short amount of time, this type of exchange and adaptation also occurs over millennia. For example, a forest ecosystem may require fire for reproduction (seed dispersal) or for soil building, but fire is also a factor of geographic context, induced by heat, lightning or levels of precipitation (Pyne, 2010). Plants and animals in a region such as this have developed over evolutionary time to be resilient to the functional factors within the system. These become part of their characteristics, prolonging their existence (Pyne, 2010; Holling, 1973).

Robert E. Cook, in his article "Do Landscapes Learn? Ecology's 'New Paradigm' and Design in Landscape Architecture," (2000) investigated how the viola plant migrates so that it can continually find an appropriate place to live. It positions itself, over generations, by dispersing its offspring in order to find nutrients and light as forest conditions change around them. In this process, many succeed, but others do not. Trial and error perpetuate a dynamic and responsive process of engaging context, so that the species can continue to succeed from within their system, over time. Charles Darwin described this framework eloquently: 
"It is interesting to contemplate an entangled bank, clothed with many plants of many kinds, with birds singing on the bushes, with various insects flitting about, and with worms crawling through the damp earth, and to reflect that these elaborately constructed forms, so different from each other, and dependent on each other in so complex a manner, have all been produced by laws acting around us."

- Darwin, Origin of Species (1839)

In Florida, these laws, or factors of context, became apparent after a canal was dredged for shipping in Tampa Bay. The spoil was set aside, creating a new pair of islands. Over time, vegetation colonized the island, and so did extreme quantities of birds, including many that are rare. It has become one of the most valued avian habitats in the Gulf (Audubon Florida, 2020b; Davis, 2017). The material and design fit within a nature that is highly regarded, both for human and landscape systems, so much so that organizations have proactively maintained the islands to perpetuate it in the face of erosion and sea level rise. In 1977, on one side of the island, an oversized sand pile was deposited (Dial \& Deis, 1986). It has since used the sea current forces, migrating to create a lagoon rich with avian habitat (figures 11 and 12).

More recently, on the other side of the island the shoreline has been protected with oyster domes and wave attenuating devices (figures 12 and 13).

As stewards, those involved have become part of the system, and will monitor this relationship into the future to guide an approach toward building within this (and future) nature(s).
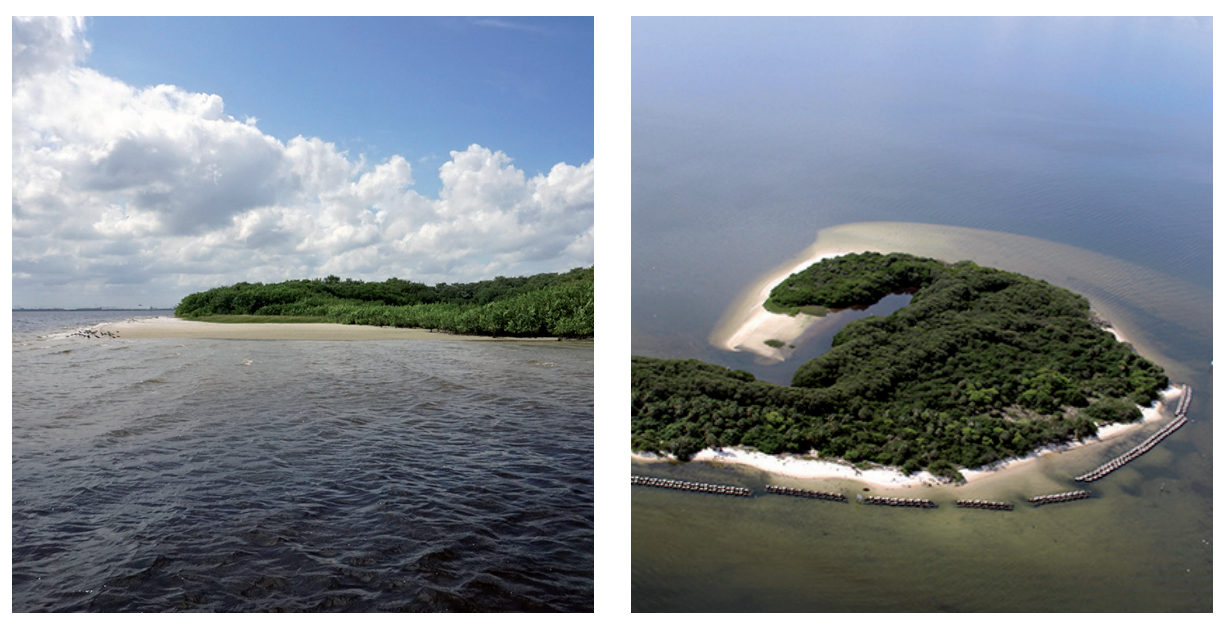

Figure 11 (left). Sand pile site, which has been allowed to curve around the island using existing flow patterns. It has created a lagoon and new habitat for avian life and waterfowl. Image by Brian Cook. Figure 12 (right). The sand pile site can be seen on the upper side of this image. On the bottom side, which faces north and the port channel, the island is protected by wave attenuation devices. Image by John Landon, courtesy of the Audubon Society. 


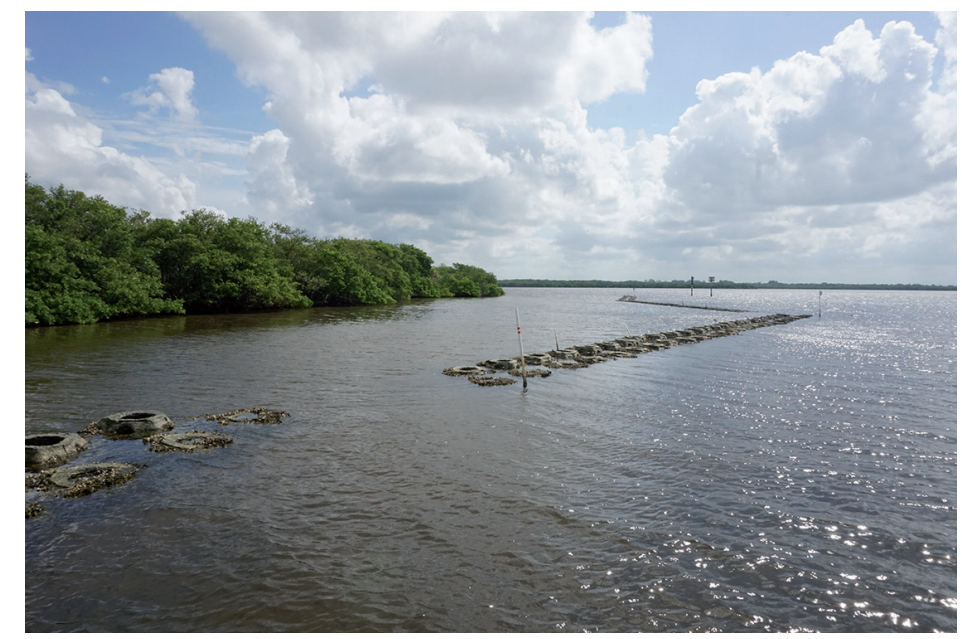

Figure 13. Wave attenuation devices on the north side of the island. Image by Brian Cook.

\section{Physical Exchanges, and Working Within}

These examples help to realize the importance of context, and time, which is connected to existing relationships and functionality of site. Like in the pond, or in the forest, projects operate within an ecosystem comprised of deeply connected and contingent relationships. These relationships extend, as does the systems functionality, to support a complex web of components, sometimes so complex it is beyond cognition (as pointed out in Principle \#1; also Carpenter et al., 2009). Displacing these functions can have calamitous results, like in the darkened bottle. For designers, Odum's study exhibits the importance of recognizing, and working with(in), the existent forces that comprise the nature of the site, over time. To build with time is an acknowledgement of context, of working within nature. It is a perspective as much as an operative procedure. If a design's success or failure depends on time spent within an ecosystem, this assumes useful participation and impact from the already established functionality of a site.

This concept of working within processes can also be considered in design, as a practice. It has been demonstrated that functional connections are built upon an exchange over time, as a physical conception. However, this also applies to project work and its relationship to the environment. Each project should be seen as part of an ongoing exchange. Through multiple and iterative exchanges at a site, humans and their constructions are able to fit their constructions to be more finely tuned to work with(in) context. Robert Cook suggests that landscape architects might consider a new paradigm in practice, acknowledging that the ecological idea is defined by processes, as "an engagement" over time (Cook, 2000). This suggests that the design project be considered in series, that each intervention is one of many in the trajectory of constructing (the nature of) a site. 


\section{Social Exchanges, and Making Amends}

In more recent ecological theory, a social-ecological dimension has been recognized as highly influential to our built environments (Folke et al., 2005). In this capacity, social-ecological thinking suggests the importance of involving the public in the landscape-making, nature-building enterprise. Not only should experts be involved in projects, but also the broad public as a political agent within (their) nature (Westley et al, 2013; Folke et al, 2005; Lister, 2008). William Jordan III discusses restoration efforts and community participation as a key human act that forms bonds and positions humans within their ecosystem. He suggests that it integrates them into "biotic citizenship," and that ultimately it induces an "ecological relationship with these systems" (Jordan III, 1994). In this manner, humans find themselves an active participant within their nature, involved in an ongoing pursuit of adaptation and exchange.

In order to address some of the aforementioned problems in Florida Gulf Coast Communities, recent social-ecological projects have operated in locations where landscape capacities were diminished by anthropogenic change. These projects ameliorate landscape ecosystem infrastructures while also introducing local populations to their environment, and environmental process. One such project occurred at MacDill Airforce Base, at the south end of the Tampa Peninsula. As part of a multi-year installation, the organization Tampa Bay Watch installed precast concrete domes and bags of oyster shells with assistance from local community members. The team placed materials slightly offshore to establish a hardened substructure with the correct texture and porosity to promote oyster growth. Behind the domes, marsh grasses were planted, extending the overall shoreline and stabilizing it through the use of biotic mechanisms (Tampa Bay Watch, 2020) (figure 14).

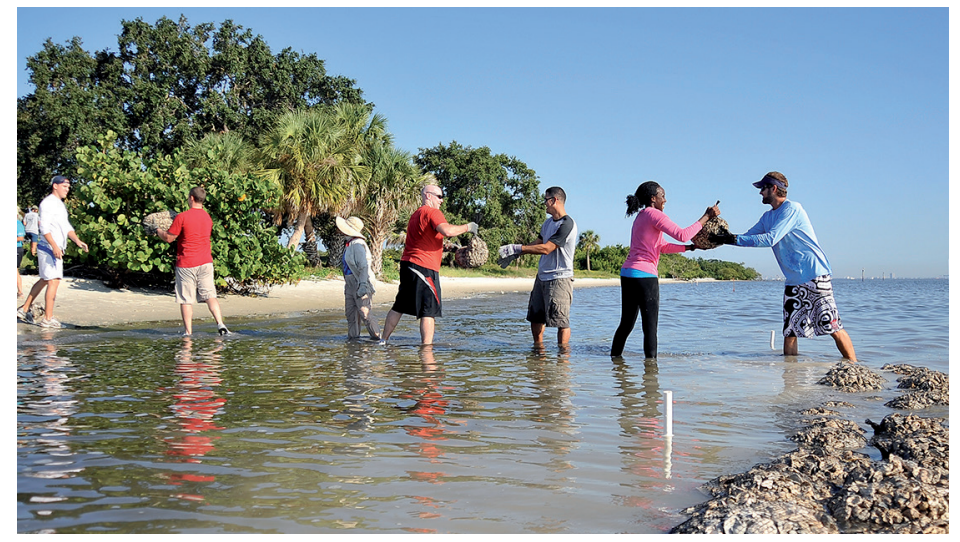

Figure 14. Volunteers place oyster bags at the MacDill Airforce Base project site. Image by Airman st Class Sarah Hall-Kirchner. 
Besides the benefits of water filtration, plant growth and benthic activity, this program has developed a human population that are working within their regional landscape system. Through the project they are able to recognize their integral role in both the making and degradation of landscape while learning about its functions and characteristics through shared experience over time.

Another project further north in Florida has accomplished similar goals but at a much larger scale. The Big Bend area is in the top portion of the Gulf on Florida's peninsula. In this flat and largely uninhabited region, freshwater seeps and flows from inland creeks and springs, mixing with the Gulf's salt water to create extremely rich estuarine environments. Human communities in the region are highly dependent on these ecosystems. They are recognized as part of human ecology, both environmentally and economically. Historically this landscape has been rich in oysters, which filter water and dissipate storm energy, protecting coastal homes and habitats (University of Florida, 2018). However in the 1970's local fisherman noticed diminished productivity. The system was changing.

A study (Seavey et. al) in 2011 found that from 1982 to 2001 there was indeed loss of oyster habitat; $66 \%$ of reefs had disappeared in general, with $100 \%$ collapse at offshore reefs. (University of Florida, 2018) Whereas overharvest is a leading threat to oysters worldwide (Beck et al. 2011), it was not found to be the problem in this instance. Instead, they found a correlation between oyster decline and low flows in the river. Their conclusion: "The usage and retention or redistribution of freshwater by human users is the main driver of the reduced discharge of the Suwannee [River]." (Seavey et al, 2011) With this knowledge, they were able to take a multi-pronged approach to promote the existing deep-time relationships in the system while accounting for, and even inducing, human influence.

A large-scale project was developed to construct a durable media for oysters to colonize. The team followed historic patterns and built linear chains of oyster bars parallel to the coast. In this location they act like a "leaky dam" and hold non-saline water close to shore while also increasing oyster productivity (figures 15,16 and 17). The reef was raised 30-60 centimeters (1-2 feet) above its current height to account for sea level rise. Limestone rock, the same rock that forms the substrate of the coastal geography, was brought to the site and installed by local contractors. In total, approximately 5 kilometers ( 3 miles) of reef were constructed at 10 meters (30 feet) wide (University of Florida, 2018). 

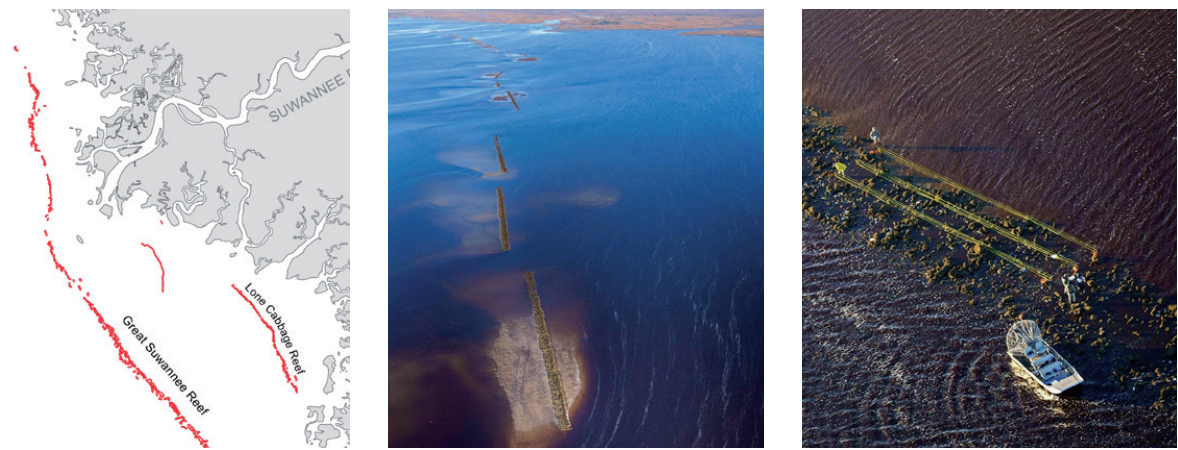

Figure 15 (left). Mapping of historic oyster reefs outside of the Suwannee River area. Map by Krystan Wilkinson, University of Florida.

Figure 16 (middle). Aerial view of installed oyster bars at Lone Cabbage Reef. Image courtesy of Carlton Ward, Jr. / Florida Wild.

Figure 17 (right). Crews take transect samples at oyster bars. Image courtesy of Carlton Ward, Jr.

So far, test sites built prior to the full-scale oyster reef project found that the design promotes more and successive growth of oyster populations. They create "ideal habitat for juvenile blue crabs and many other oyster reef-dependent animals," and are more durable substrate than found in recent conditions (University of Florida, 2018).

In these projects, time is essential, both for working within existing processes and for the participation of communities in constructing their nature. The latter projects reveal a social-ecological approach and a more iterative perspective toward Building with(in) Nature. As Nina-Marie Lister (2008) points out, "In the absence of certainty and predictability the implication for decision making is that greater participation in the process is necessary - decisions must be discussed, debated, negotiated, and ultimately learned rather than predetermined by rational choice." This negotiation occurs in a site, in situating an implemented project within its context, as well as in the planning phases. If we are to acknowledge that we work within ecosystems, both socially and physically, these processes are critical for building functional relationships (nature), which takes time.

Considering how much time it has taken for landscape systems to develop, humans are a relatively new participant. Maybe this is why we keep ourselves out of the equation and are still positioned as outsiders. This brings up a few questions: Have we positioned ourselves within the landscape system, in an exchange, over time, whereby we are perpetuating each other's existence? Are we part of that system, within and adapted to it? Or is it possible that we have been constructing an alternative nature, or ecosystem, one that is not intertwined with deep time landscape processes? If that is the case, what is our territory, and what are we adapted to? 


\section{Principle \#3: Consider Indirect Effects}

"A very important aspect in the study of ecological networks is the concept of indirect effects, that is, effects between two species that are not directly interacting, and which are mediated by other interacting species in the network. Such indirect effects can have profound influence on community dynamics." This summary by Louis-Felix Bersier (2007) helps capture the significance of the ecosystem approach. One of the most important developments and understandings from Odum's study, and his discussion of the pond, is that objects, as traditionally depicted by our ocular vision, are not sufficiently represented. In fact, their presence is the result of a web of interrelationships, contingent functionality, and interdependencies, and not all of them reside within a fixed geographic boundary of site (Bersier, 2007; Odum, 1971; Brose et al., 2005).

For example, in Southern Florida, near Fort Myers and Cape Coral, there have recently been infestations of blue-green algae, a loss of sea grass and harmful effects to coastal sea life, for both humans and non-humans. Although some portion of this is directly connected to local landscape changes, it is also influenced by hydrologic change hundreds of kilometers away.

The Kissimmee River flows from near Orlando, in central Florida, to Lake Okeechobee. From there it is discharged through the Caloosahatchee River toward the Gulf. In the 1940's severe flooding in newly urbanized areas prompted the Army Corp of Engineers to take the bends out of the 215 kilometer (134 mile) Kissimmee River and establish a 9 meter (30 foot) deep by 100 meters (300 foot) wide flood control canal with six major structures. Wetlands were filled in and cattle and housing took the place of historic meanders and marshes. As designed, the Kissimmee River Canal had much less function in the processing of nutrients than did the Kissimmee River. The water filled Lake Okeechobee more rapidly, and management of the lake included pulse flows during rainy months that pushed fresh water from the estuary into the Gulf of Mexico. This eroded sea grasses and oyster beds at the bay, impacting key components of the marine food chain. Without them, further degradation occurred since nutrients and other pollutants were not filtered out of the water (Gillis, 2018). To re-claim the functionality of this ecosystem, the Kissimmee River Restoration Project was authorized in 1992. When complete, 35 kilometers ( 22 miles) of channel will be backfilled and 71 kilometers (44 miles) of historic river channel will be restored, including 8,100 hectares (20,000 acres) of wetlands and 10,360 hectares (40 square miles) of river-floodplain ecosystem (figures 18 and 19). To accomplish this, 41,302 hectares (102,061 acres) of land were acquired. In some cases, residents were engaged to either relocate or to modify their property, but this was not possible in all stretches of the canal. In the end, total cost will approximate \$1 billion USD (USACE, 2020; SFWMD, 2010; Koebel Jr. \& Bousquin 2014). 

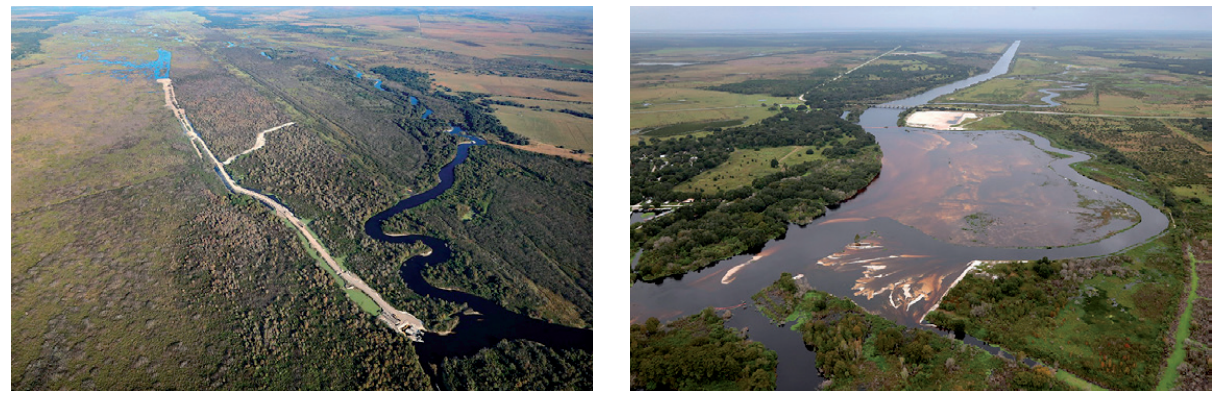

Figure 18 (left). Aerial view of the Kissimmee River Restoration Project, with backfilled channel and newly restored river corridor. Image by South Florida Water Management District.

Figure 19 (right). Flooded portion between the historic Kissimmee River Channel and the newly restored river corridor. Image by South Florida Water Management District.

After project completion in 2020, "Lake Kissimmee will rise 1.5 feet deeper each year, storing water to feed the river during the dry season and rehydrating another 30 square miles of dried marshes around it" (Audubon Florida, 2020a). Already, impacts have been seen in the uplands. One report (Audubon Florida, $2020 b)$ says that, "Wading bird numbers have surpassed restoration goals, waterfowl and shorebirds are seasonally abundant, bass and sunfish have increased, and the green, blue, and flowery beauty of the river marshes has returned." These upstream benefits will be monitored as to their effectiveness in altering the coastal ecosystem.

As in Odum's watershed description, the functionality of a site cannot be addressed locationally. As a system, its interacting components are linked by bonds of functional influence, which extend both physically and socially.

As shown in Florida, the functionality of a site cannot be determined by visual determinants but instead by an analytic investigation of contingent relationships, which cross geographic boundaries. To address the functionality of site, one cannot simply draw a boundary around it. A site is a system and should be accounted for as such.

\section{Conclusion: Towards and Ecosystem Approach}

The principles described in this chapter present a foundation from which to go forward, and to address the topic of Building with(in) Nature through a more critical lens. Key concepts from Odum, his successors, and in the Gulf Coast include:

1. Identification of and perpetuation of non-human systems within human-focused projects,

2. Working with the element of time, within existing physical and social systems, and by acting as stewards of our nature

3. The importance of working through scales, considering extended and indirect networks of impact upon a site. 
This involves a concerned and compassioned perspective, working to incorporate the complexity of our environment within built projects, and a hermeneutic process whereby humans make informed decisions and then revisit them to learn from the dynamic relationship and response from landscape, as context (see Corner, 1991). Through this exchange, relationships are constructed. In Florida, this has become first-hand experience. The ecosystem has begun to shift, providing perspective as to the response of human action, similar to the darkening of the bottle when foil was applied. However, at this time, great efforts are underway to make amends.

Odum's experiments were about opening up perception, making known the importance of all system components and their functional interrelationships, and doing this with intent, through science. His main point is to be holistic, and to consider the complexity of landscape spaces. Also, embedded in this discussion is an understanding that we are one of many forces to operate on a site. Nature is not something apart from us, but rather something that we are within. Odum cautions against a resourcist approach, and provides a useful analogy: "Man thrives best when he functions as a part of nature rather than as a separate unit that strives only to exploit nature for his immediate needs or temporary gain (as might a newly acquired parasite). Since man is a dependent heterotroph, he must learn to live in mutualism with nature; otherwise, like the 'unwise' parasite, he may so exploit his 'host' that he destroys himself" (Odum, 1963).

C.S. Holling, in his article Resilience and Stability of Ecological Systems (1973), says that "evolution is like a game, but a distinctive one in which the only payoff is to stay in the game. Therefore, a major strategy selected is not one maximizing either efficiency or a particular reward, but one which allows persistence by maintaining flexibility above all else." To do so, we must build for humans, but we must also build for our context, the one that we are dependent upon. As shown, Building with(in) Nature is a difficult and complex endeavor. It takes work and resources. But those are the stakes in the game.

Dr. Odum, an ecologist, was technical when explaining our role within nature. Martin Buber, however, as a philosopher, offers a more poetic description. He says of "life with nature":

I contemplate a tree.

I can accept it as a picture: a rigid pillar in a flood of light, or splashes of green traversed by the gentleness of the blue silver ground.

I can feel it as movement: the flowing veins around the sturdy, striving core, the sucking of the roots, the breathing of the leaves, the infinite commerce with earth and air - and the growing itself in its darkness. 
I can assign it to a species and observe it as an instance, with an eye to its construction and its way of life.

I can overcome its uniqueness and form so rigorously that I recognize it only as an expression of the law - those laws according to which a constant opposition of forces is continually adjusted, or those laws according to which the elements mix and separate.

I can dissolve it into a number, into a pure relation between numbers, and eternalize it.

Throughout all of this the tree remains my object and has its place and its time span, its kind and condition.

But it can also happen, if will and grace are joined, that as I contemplate the tree I am drawn into a relation, and the tree ceases to be an It. The power of exclusiveness has seized me.

(Buber, 1937)

\section{Acknowledgements}

The author would like to thank TU Delft and especially Dr. Steffen Nijhuis for the opportunity to contribute to this important and purposeful publication, and to the editorial board for pushing this text to become a more rich and complete account of ecosystem thinking. I thank those that provided images and descriptions of projects in Florida, including a boat trip to see rare birds on a manmade island. These people were generous and welcoming and new relationships have been made. 
Audubon Florida. (web, accessed May 4, 2020a) Kissimmee River restoration project 90 percent built and already a model for restoration. https://fl.audubon.org/news/kissimmee-river-restoration-project-90-percent-built-and-already-model-restoration

Audubon Florida. (web, accessed Feb. 9, 2020b) Sanctuary Is/ands. https://fl.audubon.org/conservation/ sanctuary-islands

Benson, K. (2000). The emergence of ecology from natural history. Endeavour, 24(2), 59-62. https://doi. org/10.1016/s0160-9327(99)01260-0

Bersier, L. -F. (2007). A history of the study of ecological networks. Biological Networks: Complex Systems and Interdisciplinary Science: Volume 3. Edited by Kepes, F. Singapore: World Scientific. 365-421.

Brose, U., Berlow, E., \& Martinez, N. (2005). Scaling up keystone effects from simple to complex ecological networks. Ecology Letters, 8(12). https://doi.org/10.1111/j.1461-0248.2005.00838.x

Brown, R. D. \& Corry, R. C. (2011). Evidence-based landscape architecture: the maturing of a profession. Landscape and Urban Planning, 100, 327-329. https://doi.org/10.1016/j.landurbplan.2011.01.017

Buber, M. (1996). I and Thou. (Kaufmann, W., trans.) Simon and Schuster. (Original work published 1937)

Carpenter, S., Folke, C., Scheffer, M., \& Westley, F. (2009). Resilience: Accounting for the noncomputable. Ecology and Society, 14(1): 13. https://doi.org/10.5751/es-02819-140113

Clements, F. E. (1916). Plant succession: an analysis of the development of vegetation. Monograph published by Carnegie Institution. https://doi.org/10.5962/bhl.title.56234

Cook, R. (2000). Do landscapes learn? Ecology's "new paradigm" and design in landscape architecture. Dumbarton Oaks Colloquium on the History of Landscape Architecture, Vol. 22, 115-132. http://www. responsivelandscapes.com/readings/ecology/COOK_DoLandscapesLearn.pdf

Corner, J. (1991). A discourse on theory II: three tyrannies of contemporary theory and the alternative of hermeneutics. Landscape Journal, 10(2), 115-133. https://doi.org/10.3368/lj.10.2.115

Corner, J. (1997). Ecology and landscape as agents of creativity. In G. Thompson, \& F. Steiner (Eds.), Ecological design and planning. John Wiley \& Sons.

Cowles, H. C. (1899). The ecological relations of the vegetation of the sand dunes of Lake Michigan. Botanical Gazette, 27(2), 95-117. https://doi.org/10.1086/327796

Cowles, H. C. (1911). The causes of vegetational cycles. Annals of the Association of American Geographers, 1(1), 3-20. https://doi.org/10.2307/2560843

Craige, B. (2001). Eugene Odum: ecosystem ecologist and environmentalist. The University of Georgia Press.

Crutzen, P. J. (2006). The "Anthropocene". In E. Ehlers, \& T. Krafft (Eds.), Earth System Science in the Anthropocene. Springer. 
Darwin, C. (1859). On the origin of species by means of natural selection, or preservation of favoured races in the struggle for life. John Murray.

Davis, J. (2017) The Gulf. Liveright Publishing Corporation.

Dial, R.S., \& Deis, D.R. (1986) Mitigation options for fish and wildlife resources affected by port and other water-dependent developments in Tampa Bay, Florida. National Coastal Ecosystems Team: U.S. Fish and Wildlife Service.

Egerton, F. (2007). Understanding food chains and food webs, 1700-1970. Bulletin of the Ecological Society of America, 88(1), 50-69. https://doi.org/10.1890/0012-9623(2007)88[50:ufcafw]2.0.co;2

Egerton, F. (2017). History of ecological sciences, part 59: niches, biomes, ecosystems, and systems. Bulletin of the Ecological Society of America, 98(4), 298-337. https://doi.org/10.1002/bes2.1337

Fletcher, D. (2008). Flood control freakology: Los Angeles River watershed. The infrastructural city: networked ecologies in Los Angeles. Actar. 36-51.

Folke, C., Hahn, T., Olsson, P., \& Norberg, J. (2005). Adaptive governance of social-ecological systems. Annual Review of Environment and Resources, 30(1), 441-473. https://doi.org/10.1146/annurev.energy.30.050504.144511

Gillis, C. (April 20, 2018). Restoration work north of Lake Okeechobee will help Fort Myers area. NewsPress. https://www.news-press.com/story/news/local/2018/04/20/northern-everglades-restoration-projects-help-lake-okeechobee-coastal-estuaries-fort-myers/498914002/

Golley, F. (1993). A History of the ecosystem concept in ecology: more than the sum of the parts. Yale University Press.

Henderson, L. (1913). The fitness of the environment. The MacMillan Company.

Holling, C.S. (1973). Resilience and stability of ecological systems. Annual Review of Ecology and Systematics, 4(1), 1-23. https://doi.org/10.1146/annurev.es.04.110173.000245

Hutchinson, G. E. (1957). A treatise on limnology. Wiley.

Ives, A. \& Carpenter, S. (2007). Stability and diversity of ecosystems. Science, 317(5834), 58-62. doi:10.1126/ science. 1133258

Jordan III, W. (1994). Sunflower forest: Ecological restoration as the basis for a new environmental paradigm. In: Beyond preservation: Restoring and inventing landscapes (17-34). University of Minnesota Press.

Koebel Jr., J, \& Bousquin, S. (2014). The Kissimmee River Restoration Project and Evaluation Program, Florida, U.S.A. Restoration Ecology, 22(3), 345-352.

Lister, N. -M. (2008) Bridging science and values: the challenge of biodiversity conservation. In D. Waltner-Toews, J. Kay, \& N. -M. Lister (Eds.), The ecosystem approach: complexity, uncertainty, and managing for sustainability. Columbia University Press, 83-107

McHarg, I. (1969). Design with nature. The Natural History Press. 
Odum, E. (1953). Fundamentals of ecology (1st Ed.). W.B. Saunders Company.

Odum, E. (1963). Ecology. Holt, Rinehart and Winston, Inc.

Odum, E. (1971). Fundamentals of ecology (3rd Ed.). W.B. Saunders Company.

Parsons, V. (2015). Giving our bays "the finger": digging up the dirt on the history of local dredging. Bay Soundings (Sept. 25). http://baysoundings.com/dredging/

PBS\&J (2010). Tampa Bay Estuary Program habitat master plan update: prepared for Tampa Bay Estuary Program. https://tbeptech.org/TBEP_TECH_PUBS/2009/TBEP_06_09_Habitat_Master_Plan_Update_Report」uly_2010.pdf

Peterson, M. \& Lowe, M. (2009). Implications of cumulative impacts to estuarine and marine habitat quality for fish and invertebrate resources. Reviews in Fisheries Science, 17(4), 505-523. https://doi. org/10.1080/10641260903171803

Pyne, S. (2010). The ecology of fire. Nature Education Knowledge, 3(10): 30. https://www.nature.com/scitable/knowledge/library/the-ecology-of-fire-13259892/

Reed, C., \& Lister, N. -M. (2014). Ecology and design: Parallel genealogies. Places Journal (2014). https:// doi.org/10.22269/140414

Riverwoods Field Lab. (web, accessed Feb. 9, 2020). The Kissimmee River Restoration History. http://www. ces.fau.edu/riverwoods/kissimmee.php

Seavey, J. R., Pine III, W. E., Frederick, P., Sturmer, L., \& Berrigan, M. (2011). Decadal changes in oyster reefs in the Big Bend of Florida's Gulf Coast. Ecosphere, 2(10):114. https://doi.org/10.1890/es11-00205.1

Shelford, V. (1913). Animal communities in temperate America, as illustrated in the Chicago region; a study in animal ecology. Publication for the Geographic Society of Chicago. University of Chicago Press

Smith, S. (2005). Florida Population Growth: Past, Present and Future. For the Bureau of Economic and Business Research, University of Florida. https://www.bebr.ufl.edu/sites/default/files/Research\%20 Reports/FloridaPop2005_0.pdf

South Florida Water Management District (SFWMD). (2010). Kissimmee River Restoration Project: Fact and tour sheet. https://www.sfwmd.gov/sites/default/files/documents/krr_krrep_factstour_sheet.pdf

Spirn, A. W. (1998). The poetics of city and nature: Towards a new aesthetic for urban design. Landscape Journal, 7(2), 108-126. Retrieved from https://annewhistonspirn.com/pdf/LJ.pdf

Steinmeyer, E. (1999). Dredging up the Butler Act. Environmental \& Land Use Law, 73(4), 69. https://www. floridabar.org/the-florida-bar-journal/dredging-up-the-butler-act/

Tampa Bay Watch (web, accessed Feb. 9, 2020). Oyster shell bars. https://www.tampabaywatch.org/oyster-shell-bars.html

Tansley, A. (1935). The use and abuse of vegetational concepts and terms. Ecology, 16(3), 284-307. https:// doi.org/10.2307/1930070 
United States Army Corp of Engineers (USACE). (web, accessed Feb. 9, 2020). Kissimmee River Restoration Project. https://www.saj.usace.army.mil/Missions/Environmental/Ecosystem-Restoration/Kissimmee-River-Restoration/

University of Florida (2018, April 10). Wildlife Ecology and Conservation: Oyster Project. https://wec.ifas.ufl. edu/oysterproject/

Weins, J. A. (1992). What is landscape ecology, really? Landscape Ecology, 7(3), 149-150. https://doi. org/10.1007/BF00133306

Willis, A. (1997). The ecosystem: an evolving concept viewed historically. Functional Ecology, 11(2), 268271. http://www.jstor.org/stable/2390328 
